\title{
O TEOLOGICZNYCH I SOCJOLOGICZNYCH PRZESEANKACH TEORII PRAWA KANONICZNEGO
}

\author{
MIEJSCE I ZADANIE TEORII PRAWA KOSCIELNEGO
}

Temat nasz ${ }^{1}$ wymaga najpierw wyjaśnienia, co rozumiemy przez teorię prawa kanonicznego i jakie jest jej miejsce wśród nauk.

Niewątpliwie sama myśl zbudowania teorii prawa kanonicznego zainspirowana jest osiągnięciami nauk prawnych, z którymi prawo kanoniczne winno być $\mathrm{w}$ kontakcie, a ich zdobycze - jeśli na gruncie kanonicznym okażą się pożyteczne - mutatis mutandis - wykorzystać ${ }^{2}$. Oczywiście nie może być mowy - co w świetle dziejów kanonistyki ostatnich dziesięcioleci wydaje się dość oczywiste - o przeszczepieniu ogólnej teorii prawa na teren kościelny ${ }^{3}$.

Celowo używamy określenia teoria prawa kanonicznego, a nie teologia prawa kanonicznego, jak to proponują niektórzy autorzy ${ }^{4}$. Po pierwsze dlatego, że nazwa ta pozwala zorientować się, o co w tej nauce chodzi, wskazuje bowiem na jej analogię do teorii prawa. Można zresztą widzieć w istnieniu takiej teorii wyraz dojrzałości metodologicznej kanonistyki, co tak bardzo leżało na sercu tzw. szkole włoskiej. Po drugie dlatego, że nazwa teologia prawa kanonicznego może łatwo wprowadzić $\mathrm{w}$ błąd co do treści i charakteru tej nauki. Sugeruje bowiem istnienie dwu odrębnych nauk o prawie kościelnym - teologii i kanonistyki. Tymczasem kanonistyka to jedna i jedyna katolicka nauka o prawie kościel-

1 Artykuł stanowi polską wersję komunikatu, przedłożonego na Międzynarodowym Kongresie Prawa Kanonicznego, urządzonym przez Wydział Prawa Kanonicznego Uniwersytetu Gregoriańskiego w dniach 14-19 lutego 1977 r. Tekst oryginalny w ,Periodica” 66 (1977), 657-681.

2 Por. A. v. Hove, Prolegomena ad Codicem Iuris Canonici, Mechliniae 1945, 576 ns.

3 Pomijając nawet względy merytoryczne nie byłoby to możliwe ze względu na wielość teorii prawa.

4 A. M. Rouco-Varela, Allgemeine Rechtslehre oder Theologie des kanonischen Rechtes? Erwägungen zum heutigen Stand einer theologischen Grundlegung des kanonischen Rechtes, „Archiv für katholisches Kirchenrecht” 138 (1969), $108-113$. 
nym, obejmująca całość tego prawa i całokształt problematyki z nim związanej, także zagadnienia fundamentalne. Nazwa ponadto teologia prawa kanonicznego niejako pośrednio eliminowałaby kanonistykę spośród nauk teologicznych, a tymczasem mimo niewątpliwego koleżeństwa po fachu z prawnikami, kanoniści mają swój dom właściwy wśród nauk tẹlogicznych, tj. tych, które przez metodyczne postępowanie wyjaśniają i rozwijają udzielone $\mathrm{w}$ wierze $\mathrm{i}$ do przepowiadania zadane Objawienie Boże ${ }^{5}$.

Wydaje się, że powyższe uwagi wystarczają dla rozwiania obaw mogących się zrodzić w związku z rodowodem teorii prawa, obliczem jej współczesnych odmian, a także $\mathrm{z}$ niektórymi dotychczasowymi doświadczeniami wiążącymi się $\mathrm{z}$ nią na terenie kanonistyki.

Termin teoria stosujemy tu w znaczeniu najogólniejszym, rozumiejąc przezeń wiedzę tłumaczącą jakąś dziedzinę rzeczywistości. Niewątpliwie rola jej $\mathrm{w}$ ramach kanonistyki byłaby podobna do roli teorii prawa, pełniącej $\mathrm{w}$ stosunku do prawa państwowego funkcję podstawową ${ }^{6}, \mathrm{kry}-$ tyczną i aksjologiczną ${ }^{7}$, niemniej jednak na gruncie kanonistycznym będzie ona przydatna tylko wtedy, gdy posłuży rozumieniu prawa kanonicznego jako prawa Kościoła - tajemnicy. I taki jest jej cel: przedstawić prawo kościelne w świetle samej tajemnicy Kościoła, odkryć w niej i wyrazić istotę prawa kościelnego, przedstawić jego cele i mechanizmy działania, wyświetlić podstawy jego obowiązywalności. Po prostu: pokazując rzeczywistość prawną Kościoła jako znak działania Bożego w historii, winna służyć jako narzędzie dla kształtowania i rozumienia porządku prawnego Kościoła.

U podstaw każdej teorii stoi pewien skonstruowany przez badacza pojęciowy model rzeczywistości ${ }^{8}$. Rzeczywistość społeczna jest bowiem bardzo złożona i dla jej poznania musi ulec uproszczeniu i strukturalizacji ${ }^{9}$. Buduje się więc pewien pojęciowy obraz rzeczywistości, nie ograniczający się jednak tylko do zwykłego schematu, w którym byłyby wyliczone rozróżnione elementy rzeczywistości, lecz określający także ich wzajemne powiązania decydujące o strukturze rzeczywistości, a także ustalający zasady działania całości10. Jest to więc pewien zespół założeń,

5 ,Theologie ist die methodisch geleitete Erhellung u. Entfaltung der im Glauben u. seinem ihm immanenten Aussagewissen gegebenen u. zur verantwortlichen Kündigung aufgegebenen Offenbarung Gottes" - J. B. Metz [w:] Lexikon für Theologie und Kirche 10,67.

6 Por. K. O pałek, J. Wróblewski, Zagadnienia teorii prawa, Warszawa $1969,358$.

7 P. J. Viladrich, Hacia una teoria fundamental del Derecho canonico, "Ius canonicum" 10 (1970), 48.

8 P. Sztompka, O pojęciu modelu $w$ socjologii, „Studia socjologiczne" 1 (1968), 51.

9 Tamże, 50 .

10 Tamże. 
w których ramach teoria się spełnia i od których zależy jej walor. Stąd ogromne znaczenie ma ujawnienie modelu leżącego u podstaw jakiejś teorii i wydobycie jej założeń.

Budowa teorii nie jest oczywiście czystą zabawą, lecz chodzi o poznanie i kształtowanie jakiejś rzeczywistości i $z$ jej punktu widzenia określa się wartość każdej teorii. Ta zaś, budowana w oparciu o przyjęty model, sprawdza się w rzeczywistości, o ile model, a więc przyjęte założenia, nie jest po prostu czystą spekulacją myślową, lecz został wyprowadzony $z$ rzetelnego poznania dostępnych danych. Tylko wtedy bowiem możemy mówić o relacji modelowej pomiędzy przyjętymi założeniami (modelem) a odzwierciedloną w nim rzeczywistością ${ }^{11}$.

Mówiąc o przesłankach teorii prawa kanonicznego chcemy wskazać na jej założenia konieczne, aby ta teoria była spójna z rzeczywistością kościelną, naprawdę ją tłumaczyła i służyła jej praktycznemu kształtowaniu. Chodzi więc o to, by teoria prawa kanonicznego mająca tłumaczyć porządek prawny Kościoła wyprowadzona była z rzetelnego poznania rzeczywistości kościelnej. Może ona bowiem mieć znaczenie dla prawa kościelnego tylko wówczas, gdy jej założenia nie będą wynikać z jakiegoś dowolnego spojrzenia na Kościól, lecz wyrażą go w świetle jego autoświadomości.

Ponieważ zaś „,samoświadomość Kościoła podlega historii i jest ciągłą wypadkową stykania się Objawienia przyjmowanego przez ludzi z coraz to nowymi sytuacjami zmieniającego się świata" ${ }^{12}$, trzeba przyjąć jako punkt wyjściowy współczesną samoświadomość Kościoła. Ustala to naszą bazę źródłową.

\section{ZAŁOŻENIE PODSTAWOWE: KOSCIOE POJETY JAKO TAJEMNICA}

Teoria mająca służyć wyjaśnieniu fenomenu prawnego Kościoła nie może u samych swych początków nie stanąć wobec pytania o istotę Kościoła. Aby wyjaśnić sobie prawo kościelne, trzeba najpierw zapytać, czym jest Kościół.

Najbardziej fundamentalna odpowiedź brzmi: Kościół jest tajemnicą. Rozumienie tego zdania w duchu nauki soborowej wyłożonej zwłaszcza w konstytucji Lumen gentium ustawia nasze spojrzenie na Kościół w perspektywie odwiecznego Bożego planu zbawczego, równocześnie zaś naprowadza nas na najbardziej charakterystyczną cechę Kościoła, mianowicie na jego złożoność. Rzecz w tym, że - jak nas o tym poucza konstytucja Lumen gentium (8) - widzialny organizm jest zarazem wspól-

11 Tamże, 52.

$12 \mathrm{Cz}$. Bartnik, Problem Kościoła jako przedmiotu historii, „Roczniki Teologiczno Kanoniczne" 22 (1975), z. 4, 54. 
notą wiary, nadziei i miłości, społeczność widzialna mistycznym Ciałem Chrystusa, że zrzeszenie widzialne i duchowa wspólnota to nie dwie odrębne rzeczy, lecz jedna, właśnie złożona rzeczywistość.

Teoria prawa kanonicznego ze względu na racje swojego istnienia nie może nie uwzględnić tego podstawowego faktu, że Kościół jest tajemnicą. Fakt ten stanowi dla kanonistyki punkt wyjściowy, podobnie zresztą jak dla całej eklezjologii. Nie może on przy tym być traktowany przez kanonistę jako fakt metakanoniczny, jako prawda przednaukowa, lecz ma dla niego znaczenie warsztatowe. Podkreślenie tego momentu jest dla naszego tematu ogromnie ważne, gdyż zajmując się prawem, które przecież jest rzeczywistością społeczną, łatwo zacieśnić obraz Kościoła do jego strony społecznej, co oznaczałoby redukcję rzeczywistości, której prawem kanonista się zajmuje. Nie można ograniczyć się do jednego aspektu Kościoła, gdyż taka abstrakcja pominęłaby istotny jego element i w efekcie na warsztacie naukowym kanonisty znalazłby się nie Kościół, gdyż ten $z$ istoty swojej jest złożony, lecz jakiś wyabstrahowany, faktycznie nie istniejący twór ${ }^{13}$.

Prawo Kościoła więc, którym zajmuje się kanonista, jest czymś z tajemnicy, jest po prostu prawem tajemnicy. Stwierdzeniu temu nie przeczy fakt, że prawo - także kościelne - jest rzeczywistością społeczną. Prawo kościelne jest rzeczywistością społeczną, ale nie wyczerpuje się w tym wymiarze. Jeśli więc chcemy naświetlić prawo jako rzeczywistość społeczną tajemnicy Kościoła, musimy przypatrzeć się miejscu rzeczywistości społecznej w tejże tajemnicy. Miejsce to i rolę konstytucja Lumen gentium tłumaczy nam przez analogię do tajemnicy Słowa Wcielonego, określając ją jako narzędzie zbawienia służące Duchowi Chrystusowemu.

Zwróćmy uwagę, że wyjaśnienie tajemnicy Kościoła podane w konstytucji przez analogię do tajemnicy wcielenia, ujęto od strony funkcji organizmu społecznego, co zresztą mieści się już w samym pojęciu narzędzia. Przez określenie funkcji podaje się, czym Kościół jest ${ }^{14}$, co oznacza, że właśnie w tym funkcyjnym przyporządkowaniu obydwu elementów mieści się charakterystyka i istota tajemnicy Kościoła.

Ujęcie istoty Kościoła w jego funkcji i z kolei określenie organizmu społecznego jako narzędzia Chrystusa zbawiającego przez swojego Ducha, otwiera przystęp do pytań właściwych prawnikowi. Mówiąc o prawie Kościoła, sięga właśnie do rzeczywistości społecznej Kościoła, ale

13 Dla zrozumienia trudności kanonistów w oswojeniu się z prawdą, że Kościól jest tajemnicą, przypomnijmy, że widzialność Kościoła kazała także niektórym ojcom soborowym odnieść się bardzo krytycznie do twierdzenia o tajemnicy Kościoła.

14 O. Semmelroth, Die Kirche als Sakrament des Heils [w:] Mysterium salutis. Grundriss heilsgeschichtlicher Dogmatik. Bd. IV, 1: Das Heilsgeschehen in der Gemeinde, Einsiedeln 1972, 309. 
widząc ją jako wyraz i narzędzie zbawienia, dociera przez to do samej tajemnicy i unika w ten sposób woluntarystycznego ujmowania prawa, wyprowadzania prawa niejako bezpośrednio z woli Chrystusa, z jakiegoś osobnego, prawotwórczego aktu Jego woli, jakby odrębnego od Jego woli zbawczej. Widząc rzeczywistość społeczną Kościoła w świetle tajemnicy zbawienia, kanonista nie musi dedukować prawa kościelnego z tekstów, których wartość dla zamierzonego dowodu nie dla wszystkich jest przekonywająca. Stąd mniejsze znaczenie wydaje się mieć odwoływanie się do „aktu” założenia Kościoła, gdyż Kościół widzimy na tle odwiecznego Bożego planu zbawczego, objawionego i zrealizowanego w Chrystusię, a uobecnianego światu przez Jego Ducha w Kościele ${ }^{15}$. Zwracamy się natomiast do fenomenu społecznego pamiętając, że rozumieć go można tylko w jego ścisłej łączności z ożywiającym go duchem Chrystusa, któremu służy jako narzędzie.

Nie rozprowadzając tutaj szerzej analogii wskazanej przez konstytucję Lumen gentium, chcemy wypunktować wypływające $z$ niej a ważne dla naszego zagadnienia wnioski ${ }^{16}$ :

1. Organizm społeczny jest prawdziwą społecznością. Żyje życiem społeczności. Wyraża się w zorganizowanej aktywności jego członków, w widzialnej strukturze, dzięki której jest dostępny naukom społecznym.

2. Organizm społeczny Kościoła pozostaje w ścisłej łączności z Duchem Chrystusa. Nie ma tu unii hipostatycznej, zachodzi nie jedność osobowa, lecz jedność działania. Jest to jednak jedność nie zewnętrzna, organizacyjna tylko, lecz cała egzystencja, działanie i skuteczność organizmu społecznego pochodzi od Ducha. Jest to jedność działania Ducha jako głównie działającego i organizmu społecznego jako narzędzia.

3. Działanie Ducha przez organizm społeczny jako narzędzie dokonuje się przez ludzi złączonych w jeden organizm, ale równocześnie zachowujących własną osobowość. Chociaż więc skuteczność działania wywodzi się nie od ludzi, lecz od Ducha, można mówić o jej zależności od ludzi, od ich faktycznego włączenia się i od ich gotowości do współdziałania. Ważną przeto jest rzeczą, by w tej jedności działania aktualizowały się i były wykorzystane wartości osobowe, zarówno naturalne predyspozycje społeczne, jak i w szczególności dary Ducha.

4. W jedności działania Ducha i organizmu społecznego jako Jego na-

15 Do ,aktu” założenia Kościoła odwołuje się wielokrotnie i jako ideę podstawową teologii prawa przyjmuje np. D. Composta: La Chiesa visibile. Lezioni di teologia del diritto, Cittá Nuova 1976, $36 \mathrm{n}$.

16 Por. na ten temat: R. Sobańs ki, De constitutione Ecclesiae et natura iuris in Mysterio Divino inteligendis, "Monitor ecclesiasticus" 100 (1975) 273 n; te nże, Modell des Kirche-Mysteriums als Grundlage der Theorie des Kirchenrechts, ,Archiv für katholisches Kirchenrecht"' 145 (1976), 22-44. 
rzędzia, odnawia się stale i konstytuuje organizm społeczny. Działając jako narzędzie zarazem rośnie jako narzędzie. Duch działa w Kościele i przez Kościół, który jest owocem, ale i zarazem łaską zbawienia. Należący do organizmu społecznego stanowią narzędzie zbawienia właśnie dlatego, że sami znaleźli się pod wpływem działania Ducha posługującego się organizmem społecznym jako narzędziem. We wierze przyjęli rzeczywistość, jaka do nich doszła w tym działaniu.

Powyższe ustalenia stanowią już wystarczającą bazę dla dalszych rozważań. Ukazuje się nam model Kościoła, uwzględniający istotne elementy i ich powiązanie. Możemy poddawać go operacjom myślowym dla wydobycia elementów teorii prawa kanonicznego. Ponieważ w modelu tym uwzględniono obydwa aspekty Kościoła wyczerpujące jego istotę, nie musimy obawiać się, że nasze dalsze ustalenia, o ile będą logicznie wyprowadzane, miną się z tajemnicą Kościoła.

\section{ZAEOŻENIA WYNIKAJĄCE Z ISTOTY KOSCIOEA}

\section{Nowa osobowość w Kościele}

Skoro do istoty Kościoła należy jego charakter prawdziwej społeczności, trzeba postawić pytanie o osoby tworzące tę społeczność i czynniki ją scalające.

Do Kościoła włącza nas nie urodzenie, lecz odrodzenie we chrzcie. Nie nasza decyzja, czy tylko nasze skłonności społeczne, lecz działanie Boże włącza w tę społeczność. Nie narodowość, zainteresowania własne, lecz wiara, nadzieja i miłość, jakie zostały nam dane i przez nas przyjęte, łączą nas w Kościół. Stajemy w Kościele wobec siebie nie jako Żydzi czy Grecy, niewolnicy lub wolni, mężczyźni lub niewiasty( por. Gal 3, 28), lecz jako ci, którzy mają nowe istnienie w Chrystusie; nie jako ludzie tylko narodzeni, lecz jako odrodzeni, wyposażeni w łaskę synów i wspólne powołanie do zbawienia. Obdarowanie ze strony Boga czyni nas osobami w Kościele, określa nasze w nim miejsce i stanowi treść naszej kościelnej osobowości. Inkorporacja w Kościół stwarza nową sytuację bytową człowieka mającego swoje esse w Mistycznym Ciele Chrystusa.

Faktu tego nie wolno przeoczyć w rozważaniach o prawie kościelnym. Co więcej, rozważania te, jeśli przyjmują jako punkt wyjściowy człowieka - co uzasadnia się tym, że prawo jest rzeczywistością antropologicz-ną - muszą wyjść właśnie od człowieka mającego egzystencję w Chrys" tusie. Moment ten wymaga szczególnego podkreślenia dlatego, że mimo kan. $87^{17}$, gdy w prolegomenach do prawa kościelnego wskazuje się na

17 Dodajmy jednak, że Kodeks Prawa Kanonicznego jest niekonsekwentny, gdyż od razu po kan. 87, wskazującym na czynnik nadprzyrodzony, następują kanony 
jego konieczność i rolę, bardziej nawiązuje się do skażoności natury ludzkiej i skutków tegoż skażenia, niż do faktu odkupienia człowieka i wyposażenia go darami. Tymczasem zaś w każdym systemie prawnym człowiek będący jego podmiotem musi być uwzględniony w swej konkretnej sytuacji antropologicznej. Ta zaś określona jest w Kościele przez łaskę chrztu. Stanowi ona realność, której nie można pominąć. Człowiek realnie istniejący $\mathrm{w}$ Kościele, to czlowiek odkupiony, mający egzystencję w Chrystusie.

\section{Specyfika relacji międzyosobowych i treść sprawiedliwości w Kościele}

Czynniki decydujące o osobowości kościelnej stanowią też podstawę relacji międzyosobowych w Kościele. Wiara, nadzieja i miłość łączy ludzi w Kościół - z wiarą, nadzieją i miłością stają też wierni wobec siebie. Dar wiary uzyskany został we wspólnocie kościelnej po to, by go dalej przekazywać. Wyposażenie zyskane we chrzcie jest tym, co się drugim od nas należy. Mówiąc inaczej, stanowi ono treść sprawiedliwości w Kościele. Dla prawnika sprawiedliwość stanowi punkt widzenia rzeczywistości i o realizację sprawiedliwości mu chodzi. To samo dotyczy także kanonisty. Musi on postawić sobie pytanie, co jest treścią sprawiedliwości w Kościele, co winien jeden drugiemu w tej społeczności?

Otóż człowiek ochrzczony winien drugiemu to, co sam otrzymał do przekazania. Ujawnia to specyfikę sprawiedliwości w Kościele. We wszystkich innych społecznościach rozróżnia się między sprawiedliwością i miłością. Również na teren kościelny przenosi się rozróżnienie między zobowiązaniem ex iustitia i ex caritate. Prowadzi to do gradacji zobowiązań, do widzenia w życiu Kościoła dwu płaszczyzn, sprawiedliwości i miłości, a w efekcie do rozróżnienia między Kościołem prawa i Kościołem miłości. Tymczasem takie rozróżnienie między Kościołem prawa i Koścıołem miłości nie ma racji bytu, podobnie jak nie może być w Kościele dwu płaszczyzn, sprawiedliwości i miłości. Istnieje bowiem tylko jedna płaszczyzna życia Kościoła - jest nią płaszczyzna miłości. Ta bowiem charakteryzuje i wyróżnia chrześcijan, bez niej jest się po prostu niczym (1 Kor 13). Dzieje się tak dlatego, że miłość, jako dar udzielony przez Boga, należy do wyposażenia osoby w Kościele, jest treścią osobowości kościelnej. Stajemy wobec drugich osób jako wyposażeni w miłość i miłość ta im się należy. Miłość i jej realizacja mieści się więc w sprawiedliwości. Bez miłości nie można być w Kościele sprawiedliwym. Nie miłując nie daje się drugiemu tego, co mu się należy.

traktujące o naturalnych podstawach osobowości w Kościele. Por. R. S o bańs k i, Sakramentalne podstawy pozycji prawnej wiernych w Kościele, „Prawo Kanoniczine" $13(1970)$ s. $143-157$. 
Podobnie ma się rzecz z wiarą, nadzieją i wszystkimi innymi darami. Jako należące do nadprzyrodzonego wyposażenia człowieka stanowią dla niego zadanie do realizacji i należą do treści sprawiedliwości w Kościele.

Sprawiedliwość jest więc realizowana w Kościele wówczas, gdy jeden daje drugiemu to, co dla świadczenia wspólnocie otrzymał, gdy daje świadectwo $\mathrm{w}$ wierze i nadziei, urzeczywistnia miłość, wykonuje posłannictwo, buduje więzi wspólnotowe $\mathrm{w}$ oparciu o rozmaitość łask i posług danych dla gromadzenia w jedno synów Bożych ${ }^{18}$.

Jest oczywiste, że w realizacji sprawiedliwości dochodzą do głosu i aktualizują się także naturalne predyspozycje człowieka. Dar wiary niє mógłby być podstawą więzi międzyludzkich ani nie mógłby być przekazywany, gdyby człowiek nie był istotą otwartą na wartości. Dar miłości nie mógłby być realizowany w egzystencji ludzkiej, gdyby w naturze ludzkiej nie tkwiło jej zorientowanie ku drugiemu człowiekowi. Predyspozycje ludzkie stapiają się z rzeczywistością Bożą.

Sprawiedliwość więc realizujemy w Kościele, gdy przekazujemy otrzymane, a przeznaczone do przekazywania dary i przez to zacieśniamy więzy międzyludzkie. Jest to budowanie wspólnoty ludzkiej opartej na przyjętych i przekazywanych darach Bożych, a więc wspólnoty ludzi będącej zarazem wspólnotą z Bogiem.

Sprawiedliwość w Kościele jest więc sprawiedliwością wspólnoty budowanej na więzi z Bogiem, w której to, co się drugiemu należy, płynie od Tego, który swoimi darami wspólnotę tę konstytuuje. Jest to więc sprawiedliwość, która będąc rzeczywistością międzyludzką nie może ",w swoim rachunku" nie uwzględnić Boga. Relacje międzyosobowe w Kościele realizujące sprawiedliwość są nie do oderwania od relacji do Boga, sa znakiem tej relacji. To zaś nadaje sprawiedliwości w Kościele nie tylko nowy wymiar, ale wpływa na jakość zobowiązania wynikającego ze sprawiedliwości.

3. Communio jako wartość realizowana w działaniu społecznym Kościoła

Sprawiedliwość pojęta jako wymiar wspólnoty z Bogiem pozwala nam rozumieć wartości realizowane w Kościele, do których zorientowane jest prawo kościelne. Nauki społeczne używają w tym kontekście określenia dobro ws pólne. Dla prawa jest to jedno z węzłowych pojęć, pozwala bowiem określić jego zasadę formalną. Dobrem wspólnym Kościoła jest wspólnota $\mathrm{z}$ ukrzyżowanym i zmartwychwstałym Chrystusem

18 Por. Lumen gentium 32. 
sprawowana w nas za sprawą Ducha Świętego 19. Tę właśnie wspólnotę otrzymujemy jako dar wiary, nadziei i miłości. Jest ona antycypacją i znakiem wiecznej i nieutracalnej już wspólnoty, do której zmierzamy. Kościół jest znakiem i realizacją rzeczywistości eschatologicznej, do której jako do pełni zdążamy. Jako wspólnota ludzi stanowi znak i zapoczątkowanie zamierzonej jedności ludzkości przez to, że dzięki obecności i działaniu Ducha Sw. w Kościele, jest on wspólnotą Boga i ludzi. Wspólnota ta jest darem i zadaniem do zrealizowania. Do jej realizacji zmierza i zorientowana jest cała działalność Kościoła. Wspólnota ta może być realizowana w działaniu Kościoła dzięki temu, że jako głównie działający jest w niej obecny Duch, któremu organizm społeczny służy jako narzędzie. Organizm ten spełnia swą funkcję wtedy, gdy świadczy o wierze, nadziei, miłości — o tych wszystkich darach, dzięki którym rzeczywistość Boża stała się naszym udziałem. Dawanie świadectwa to właśnie przekazywanie tej rzeczywistości, jej realizacja, po prostu budowanie wspólnoty Bosko-ludzkiej.

Dawanie świadectwa jest społeczną, zewnętrzną formą działania, dostępną dla prawnika i interesującą kanonistę. Kanonista przyjmuje istniejąca rzeczywistość wiary i pyta, jakie formy prawne byłyby najbardziej odpowiednie dla wartości otrzymanych przez człowieka w wierze, aby im dawał świadectwo. Faktem podstawowym jest więc rzeczywistość wiary, mająca wyrazić się $w$ działaniu ludzkim. Dla niej to szuka się form prawnych.

Problem interesujacy kanonistę to nie tylko organizacja zewnętrznego działania, przez które dawane jest świadectwo, lecz przede wszystkim synchronizacja zewnętrznego, prawem normowanego działania z życiem wewnętrznym. Chodzi o to, by struktury prawne Kościoła nie były strukturami tylko administracyjnymi, ale strukturami życia łaski. By kształtowane przez prawo relacje międzyosobowe nie były tylko zewnętrzne, ale znakiem spotkania się ludzi z Panem. Legalizm nie wystarcza do budowania wspólnoty - prawo kościelne, jeśli ma mieć jakiś sens, musi sięgać znacznie głębiej. Jest to problem niezmiernie trudny, w praktyce legislacyjnej chyba węzłowy i decydujący o koncepcji prawa kościelnego.

Na płaszczyźnie teoretycznej należy w tym kontekście na pierwszym miejscu wskazać na kształtującą świadomość rolę prawa. Jeśli prawo ma sięgać do wewnętrznego aktu woli ludzkiej akceptującej wspólnotę, to trzeba w teorii prawa kościelnego położyć nacisk na informacyjną i kształtującą świadomość rolę prawa ${ }^{20}$.

19 J. Krucina, Dobro wspólne. Teoria $i$ jej zastosowanie, Wrocław 1972, 355.

20 I. M i erzwa, Das Recht als ein die Aktivität der Gemeinschaft auslösender Faktor [w:] III Congreso Internacional de Derecho Canonico (Edicion provisorial). 
Drugie zagadnienie, jakie należy podnieść, to koncepcja prawa kościelnego. Zwrócono uwagę, że organizacja prawna współczesnych społeczeństw opiera się albo na systemach zezwalających, albo na zakazujących ${ }^{21}$. Można je scharakteryzować $w$ ten sposób, że w pierwszym dozwolone jest wszystko, co nie jest wyraźnie zakazane, a w drugim zakazane wszystko, co nie jest wyraźnie dozwolone. Chodzi o to, by prawo kanoniczne dawało wolność i możliwość działania i wręcz to działanie prowokowało. Jest to dla prawnika logiczną konsekwencją, wynikającą z założenia, że u podstaw prawa kościelnego stoi człowiek o bogatym wyposażeniu, powołany do dawania świadectwa i budowania wspólnoty. Prawo w tej perspektywie jest czynnikiem, który stwarzając pola aktywności i kształtując relacje międzyosobowe, pozwala dojść do głosu wiernemu, powołanemu jako osoba do tego, by uczestnicząc w działalności społecznej Kościoła, wyrażał i przekazywał to, co jako dar i zadanie wspólnoty otrzymał. Ponieważ ta dana i zadana do świadczenia wspólnota jest wartością realizowaną przez Kościół, stanowi ona kryterium dla kształtowania jego struktur prawnych.

\section{AKTYWNOSC PRAWNA JAKO ŚRODEK PRZEKAZU WIARY}

1. Działalność prawodawcza ujęciem kościelnego życia z wiary

Działanie, przez które wspólnota daje świadectwo, jest znakiem i narzędziem działania Ducha. Znaczy to, że wyprzedza ono działalność prawodawczą i że ta ostatnia staje wobec już istniejącego działania społecznego Kościoła. Działanie to - jako działanie społeczne - ma immanentny wymiar prawny. Należy przeto do prawników w Kościele odczytać ów wymiar.

Tym samym dochodzimy do wyświetlenia sposobu, w jaki rzeczywistość wiary dostaje się na warsztat prawników. Znajdują ją w Kościele i w postaci realizowanej przez Kościół. Wiarę poznaje się w Kościele i przez Kościół: z jego nauczania, liturgii, życia chrześcijańskiego - w służbie bowiem uobecniania $\mathrm{w}$ historii prawdy i łaski zbawienia stoi cała działalność Kościoła: przepowiadanie, wyznawanie wiary, sakramenty, życie chrześcijańskie ${ }^{22}$. W życiu wspólnoty chrześcijańskiej kanonista znajduje dostępną dlań, wyrażoną w społecznym wymiarze, rzeczywistość wiary.

Prawo kościelne jest więc ujęciem kościelnej formy realizacji wiary, która - podobnie jak i inne dary dane dla dobra całości - jest czyn-

21 W. Steinmüller, Der Entwurf der Lex Ecclesiae Fundamentalis. Ein Klerikerrecht der Laien?, ,Theologische Quartalschrift” 157 (1972), 328.

${ }^{22} \mathrm{R}$. S o bański, Ustawa kościelna - „ordinatio rationis” czy ,ordinatio fidei?”, „Collectanea Theologica” 48 (1978), z. 1, 33. 
nikiem scalającym wspólnotę i środkiem komunikacji. Z istơty swojej rodzi przeto formy życia społecznego. Tu znajduje się wytłumaczenie, w jaki sposób można rzeczywistość nadprzyrodzoną „dostać" na warsztat kanonistyczny, gdyż z istoty swojej tworzy ona formy życia wspólnotowego.

Miejsce prawodawcy kościelnego jest nie przed życiem Kościoła, lecz w nim, on tkwi w tym życiu, poznaje je i ujmuje. Formułowanie norm prawnych dokonuje się podobnie jak formułowanie ujęć dogmatycznych. Wiarę obecną w Kościele ujmuje się wciąż, bo ona jest do głoszenia i realizacji. Ujmuje jako coś wciąż aktualnego, bo jest ona ciągłą rzeczywistością Boga się udzielającego. Podobnie ujmuje się życie Kościoła jako wciąż żywą rzeczywistość wspólnoty Boga z ludźmi.

\section{2. Źródło normy obowiązującej prawa kościelnego}

Dochodzimy tym samym do najgłębszych podstaw mocy obowiązującej prawa kościelnego, która nie da się wytłumaczyć kategorią iussum legitimi principis, nawet jeśli podbuduje się ją argumentami o charakterze teologicznym, nie powiązanymi jednak ściśle $z$ podstawowymi prawdami naszego porządku zbawienia.

Moc zobowiązująca prawa kościelnego płynie $z$ wiążącego charakteru życia chrześcijańskiego jako świadectwa i realizacji objawionej nam prawdy i miłości. To normatywne ujęcie życia Kościoła pozostaje wprawdzie wtórne w stosunku do tegoż życia, ale jako ujęcie realizowanej w życiu wiary jest wiążące i przez to formuje życie - podobnie jak formuje ją dogmatyczne ujęcie prawd wiary, acz wtórne w stosunku do niej jako wiążące ujęcie głoszonej wiary ${ }^{23}$. Widzimy tu więc żywy proces, w którym prawodawca kościelny tkwiąc w życiu wspólnoty, poznając je i szukając dlań możliwie najodpowiedniejszych form prawnych, przyczynia się do nadawania mu kształtu.

W ten sposób, jak sądzę, rysują się właściwe perspektywy prawa kościelnego: jest ono jednym ze środków przekazu wiary. Prawne ujęcie poznanej poprzez Kościół wiary przekazuje ją w konkretną sytuację egzystencjalną człowieka i społeczności. Jest inkarnacją prawdy i miłości w życie. Działalność prawna stanowi jedną z form przekazu Ewangelii i jej wartości, rozbudowuje porządek miłości, wciela miłość w formy działania wspólnoty, widoczne dla świata. Podobnie jak dla przekazywania Ewangelii przez słowo głoszone szuka się najlepszych możliwości tkwiących w środkach komunikacji, tak też dąży się do wykorzystania w służbie przekazu Ewangelii możliwości tkwiących w prawie. Wykorzystanie na gruncie kościelnym osiągnięć nauk prawnych jest takim samym obo-

23 Tamże, 34 . 
wiązkiem pastoralnym, jak szukanie najlepszych form przekazu słowa czy ukształtowania liturgii ${ }^{24}$. Zadanie przekazywania wiary, a nie świecka działalność ustawodawcza, stanowi punkt widzenia teorii prawa kościelnego.

Takie podejście do sprawy wymaga podkreślenia jedności porządku kanonicznego. Twierdzenie bowiem, że prawo kościelne ujmuje życie Kościoła jako formę realizacji wiary, oznacza, że prawodawca kościelny w samym centrum tego życia natrafia na rzeczywistość Bożą: na Boga jako objawioną $w$ słowie prawdę i przez Ducha wlaną miłość, na ujawniający się w życiu wspólnoty porządek wiążącej miłości, stanowiącej po prostu prawo Boże. Rozbudowując życie wspólnoty prawo kościelne rozwija i historycznie aktualizuje prawo Boże: rozbudowuje rzeczywistość międzypodmiotową zgromadzonych w imię Pana, w której On zapewnia swoją obecność. Z tej rzeczywistości wypływa prawo Boże, na niej się opiera i jest jej historycznym świadectwem.

\section{Prawo a wolność w Kościele}

Traktowanie prawa kościelnego jako środka przekazu wiary oraz wiążąca się $z$ tym jedność prawa pochodzenia Bożego i kościelnego daje specyficznie kościelne piętno zagadnieniu prawo a wolność, którego w ramach teorii prawa kanonicznego nie można pominąć.

Prawo Boże, równoznaczne z porządkiem miłości, jest darem danym człowiekowi i wymagającym wolnego przyjęcia. Darem wiary jest wspólnota, jaką Bóg w Kościele i przez Kościól ofiaruje. Realizuje się ją przez ludzi, którzy wolnym aktem przyjęli dar wiary, to znaczy łaskę zbawienia ofiarowaną im przez Chrystusa w Kościele. Jeżeli zaś mówimy o jedności porządku prawnego Kościoła, to wyciągamy $\mathrm{z}$ tego wniosek nie tylko o zbawczym charakterze i działaniu całego prawa kościelnego, lecz również, że także prawo kościelne (pochodzenia kościelnego) trzeba widzieć jako dar.

Prowadzi to do stwierdzenia, że wolność jest fundamentalną zasadą całego porządku prawnego Kościoła. Rozumiemy je w ten sposób, że zagadnienie wolności $\mathrm{w}$ odniesieniu do prawa kościelnego winno być rozpatrywane w oparciu o te same przesłanki, które rządzą zagadnieniem wolności w całym naszym porządku zbawienia. Jest to konsekwencja faktu, że ofiarowana przez Boga prawda i miłość wzywa człowieka do jej przyjęcia aktem wiary i do realizacji 25 .

24 R. Sobański, Dokąd zmierza prawo kościelne?, „Collectanea Theologica" 47 (1977), z. 3, 11.

${ }_{25}$ R. S obański, Prawo a wolność osoby odrodzonej we chrzcie, „Prawo kanoniczne" 20 (1977), nr 3-4, s. 47-64. 


\section{Zagadnienie recepcji prawa w Kościele}

Rysuje się przeto konieczność zwrócenia uwagi na zagadnienie recepcji prawa kościelnego. Wgłębienie się w nie może przyczynić się do wypunktowania i naświetlenia specyfiki recepcji prawa w Kościele, a w konsekwencji specyfiki prawa kościelnego w ogóle. Stosowane dotychczas podejścia do tego zagadnienia pozostają w sferze prawno-teoretycznej i uwzględniają jedynie jego aspekty formalne. Aspekty te, jak i wzgląd na zabezpieczenie porządku publicznego, wystarczające na terenie innych społeczności, są zbyt ubogie w odniesieniu do ustaw kościelnych, jeśli te mają być formą przekazu wiary. Jeszcze raz okazuje się, jak nieadekwatne do rzeczywistości kościelnej pozostają rozważania prowadzone wyłącznie na płaszczyźnie prawno-teoretycznej i jak konieczna jest właśnie autentycznie kanoniczna teoria prawa kościelnego.

Odnośnie do zagadnienia recepcji prawa kościelnego trzeba powiedzieć, że podobnie jak przyjęcie Ewangelii i jej wartości nie może być obojętne dla tych, którzy ją głoszą, tak też nieobojętne jest przyjęcie prawa stanowionego $\mathrm{w}$ Kościele, jeśli jest ono jedną $\mathrm{z}$ form inkarnacji Ewangelii w życie. Stąd obok zagadnienia recepcji wiary nauczanej, istnieje w Kościele również problem recepcji prawa ${ }^{26}$, wymagający naświetlenia przy zastosowaniu wszystkich kategorii istotnych dla rzeczywistości prawnej Kościoła ${ }^{27}$.

\section{SOCJOLOGICZNE PRZESEANKI TEORII PRAWA KOSCIELNEGO}

\section{Relacja Kościót - świat jako baza zagadnienia}

W tytule jest mowa o przesłankach teologicznych i socjologicznych. Jako teologiczne potraktowaliśmy te, które wynikają z istoty Kościoła. Przesłanki natomiast, które według tytułu zakwalifikowaliśmy do socjologicznych, wypływają z faktu istnienia i działania Kościoła przez wieki, Ich wynikający stąd charakter spróbujemy jeszcze określić pod koniec artykułu.

Problem przesłanek socjologicznych sprowadza się w istocie rzeczy do dwu pytań:

(1) Jaki wpływ wywierają na prawo kościelne konkretne warunki istnienia Kościoła?

(2) W jakiej mierze prawo kościelne zależy od aktualnej kultury prawnej?

${ }^{26} \mathrm{Y}$. M. Congar, La réception comme réalité ecclésiologique, „Revue des sciences philosophiques théologiques" 57 (1973), 369-403.

27 W. A y mans, Die Quellen des kanonischen Rechts in der Kodifikation von 1917 [w:] III Congreso Internacional de Derecho Canonico (Edicion provisorial). 
Pytania te stawiamy na płaszczyźnie teoretycznej. Chodzi nie o wpływ faktycznie w określonym czasie wywierany, lecz o historycznie uwarunkowane czynniki, konieczne dla zrozumienia i przedstawienia rzeczywistości prawnej Kościoła.

Odpowiedź na pierwsze pytanie mieści się w całym kompleksie zagadnień Kościót - świat. Nasz temat wymaga przypomnienia, że Kościół istnieje jako znak zbawienia. Sam w sobie ,,jest powszechnym sakramentem zbawienia ukazującym i zarazem realizującym tajemnicę miłości Boga" (Gaudium et spes n. 45). Istnienie ad extra należy do jego istoty. Inaczej Kościól w ogóle nie może być pojmowany - czym tłumaczy się fakt, że rozwój eklezjologii był zawsze konsekwencją pogłębionej refleksji Kościoła nad swoją misją dla świata. Refleksja ta, będąca przecież wnikaniem $\mathrm{w}$ tajemnicę, ma w swojej optyce nie tylko „sam Kościół”, lecz obejmuje także określoną wizję świata. Kościół widzi siebie zawsze w świecie mu współczesnym i dopiero na tym tle może zrozumieć siebie jako znak zbawienia.

Właśnie fakt, że ta bogata, nie do zdefiniowania rzeczywistość, jaką jest Kościól, istnieje dla ludzi i tylko w tym istnieniu może być pojmowana, powoduje, że w zależności od konkretnej sytuacji kulturowej, od potrzeb ludzi i pytań przez nich stawianych, w różnych epokach różne aspekty wysuwają się na pierwszy plan i różne dominują ujęcia Kościoła. Ponieważ problem Kościót - świat i ich wzajemne przenikanie jest elementem świadomości Kościoła oraz ujmującej ją eklezjologii, a równocześnie oczywiste jest, że teoria prawa kanonicznego nie może nie odpowiadać aktualnej świadomości Kościoła, od której zależy, ale którą - jako nauka o Kościele - też kształtuje, możemy nasze rozważania skoncentrować na kręgu problemowym podyktowanym drugim pytaniem.

\section{Struktury prawne Kościoła w służbie światu}

Traktując wzajemne przenikanie się treści kulturowych między Kościołem i światem jako problem eklezjologiczny, a tym samym pośrednio, przez odpowiednią wizję Kościoła, wpływający na prawo kościelne, musimy jednak na płaszczyźnie teorii prawa zaakcentować jeden moment bezpośrednio związany $\mathrm{z}$ istnieniem Kościoła jako znaku zbawienia w historii. Chodzi tu o rolę struktur prawnych Kościoła w jego służbie światu.

Jeśli Kościół istnieje jako znak dla świata, to jego struktura i organIzacja prawna służy nie tylko dobru wspólnoty i jej członków, ale jest podporządkowana celowi Kościoła ad extra. Organizacja prawna życia 
wspólnoty winna być manifestacją prawdy i miłości, której wspólnota jest świadkiem; ma być czytelnym znakiem łaski żyjącej we wspólnocıe i przez nią się rozlewającej. Prawo kościelne nie może przeto być widziane jako narzędzie służące tylko Kościołowi, lecz winno przezeń służyć całej ludzkości. Jest to oczywiste dla każdego, kto pojmuje Kościół nie jako zamkniętą, samą siebie celebrującą społeczność, lecz jako manifestację miłości Bożej.

Jest to więc postulat czytelnych jako znak laski i otwartych struktur prawnych. Zagadnieniu struktur otwartych warto na terenie teorii prawa kościelnego poświęcić trochę uwagi. Depozyt Boży istnieje bowiem w Kościele po to, aby był przekazywany. Głoszenie i realizacja wiary i miłości w ciągle zmieniających się sytuacjach ludzkich i związana $z$ tym konieczność poszukiwania form odpowiednich dla tych sytuacji wymaga, by prawo kościelne było otwarte na doświadczenia ludzkie - prawne, społeczne, kulturowe, na wszystkie te dobra i wartości, które moga być czynnikami nośnymi Ewangelii i sprzyjać wzrostowi i zwiększeniu aktywności społecznej Kościoła ${ }^{28}$.

Otwartość w odniesieniu do prawa rozumiemy jako strukturalny kształt wspólnoty istniejącej dla świata i ludzkości, odpowiadającej także poprzez organizację życia wspólnotowego ${ }^{29}$ - na wciąż nowe pytania, ale równocześnie też zdobywającej wciąż nowe środki wyrażania ${ }^{30}$, wchłaniającej i tym samym chrystianizującej. Zagadnienie to jest niewątpliwie trudne, gdyż prawo ma w tym wypadku nie tylko zadanie ułatwiania procesów przenikania, ale ma być też czynnikiem zachowania tożsamości. Dla problemu tego wielce instruktywne może być wykorzystanie doświadczeń wspólnot chrześcijańskich ${ }^{31}$.

\section{3. Łączność prawa kościelnego z aktualną kulturą prawną}

Jako typowe zagadnienie teorii prawa kościelnego można określić problem łączności prawa kanonicznego z kulturą prawną. Z konieczności musi on w tym miejscu być potraktowany bardzo szkicowo. Jego wiodące elementy podano już wyżej. Kościół winien być czytelny także w swoich strukturach prawnych, nie może więc tkwić w ariergardzie współczesnej mu kultury prawnej. Ponadto, co już wspomniano, prawo jest

${ }_{28}$ R. S o ba ński, De constitutione Ecclesiae, 293.

${ }^{29}$ R. Sobański, Inspiracje dla zagadnienia rozwoju wypływajace $z$ pojęcia communio, „Ślasskie Studia historyczno-teologiczne” 8 (1975), $266 \mathrm{n}$.

${ }_{30}$ Y. M. C. Conga r, Historia Kościoła „miejscem teologicznym”, „Concilium" 6-10 (1970) Poznań 1971, 99.

31 I. M i erzwa, Stosunek Kościót - świat jako element $w$ dyskusji nad prawem fundamentalnym Kościoła, "Prawo kanoniczne" 19 (1976), $\mathrm{nr} 1-2,126 \mathrm{n}$. 
jednym ze sposobów przekazywania Ewangelii. Stąd konieczność, by rozwój prawa kościelnego był współbieżny z rozwojem nauk prawnych. Jest to po prostu zadanie pastoralne, wynikające $\mathrm{z}$ samej misji Kościoła ${ }^{32}$.

Spożytkowanie jednak odzwierciedlonego w stanie nauk prawnych rozwoju nauk społecznych (a więc wykorzystanie wykształconych tam pojęć, metod, technik) nie może dokonywać się w sposób niezróżnicowany. Prawo kanoniczne jest tu w sytuacji podobne: do innych nauk teologicznych, w których przejęte wyrażenia (np. filozoficzne) przechodzą swoistą mutację ${ }^{33}$. Przejęcie przez nauki kościelne przydatnych dla przekazu wiary pojęć, inspiracji i metod nie oznacza ich aneksji, lecz pociąga za sobą ich modyfikację na użytek wiary. Również historia prawa kościelnego dowodzi modyfikowania przejmowanych instytucji i metod prawnych ${ }^{34}$, równocześnie zaś - także najnowsza - ilustruje, jakie trudności mogą się zrodzić, gdy stosowanie zdobyczy świeckiego prawa dokonuje się bez uwzględnienia specyfiki terenu kościelnego ${ }^{35}$.

Właśnie teoria prawa kościelnego może dostarczyć klucza rozwiązującego czy przynajmniej naświetlającego to zagadnienie. Dodajmy, że proponowana przez nas teoria prawa kościelnego jest właśnie eklezjalną modyfikacją inspiracji przychodzącej z nauk prawnych.

\section{Teologiczny wymiar przesłanek socjologicznych}

Przytoczone wyżej spostrzeżenia o przesłankach socjologicznych prowadzą do wniosku, że są to $\mathrm{w}$ istocie rzeczy przesłanki teologiczne. Wynikają one - jak wspomniano - z faktu istnienia i działania Kościoła przez wieki. Ale to właśnie należy do jego istoty. Jeśli Kościół może być rozumiany tylko w perspektywie jego kontaktu ze światem i jego w nim egzystencji, to wówczas czynniki wyznaczające świat - czas, miejsce, kultura - stają się czynnikami teologicznymi, stanowią po prostu pewną kategorię teologiczną jako miejsce realizacji Ewangelii. Bez nich Kościół jest nie do pomyślenia. Historia Kościoła jest zarazem historią jego świa-

32 R. Sobański, El lugar y las funciones de la canonistica en la vida de la Iglesia, „Ius canonicum” 16 (1976), 295.

33 A. Z u b e r bi e r, Teologia dzisiaj, Katowice 1975, 56.

34 C. G. F ür s t, Ecclesia vivit lege romana? „Zeitschrift der Savigny Stiftung. Kanonistische Abteilung" 51 (1975), 30.

${ }^{35}$ Rzecz oczywista, że na płaszczyźnie teorii prawa trzeba wykorzystać także wnioski wynikające $\mathrm{z}$ doświadczeń historycznych - takich jak recepcja prawa rzymskiego czy germańskiego, sięgnięcie po metodę kodyfikacji, próby stosowania w kanonistyce ogólnej teorii prawa, wreszcie podjęcie idei kodyfikacji prawa fundamentalnego. Właśnie taka historyczna analiza wskaże pożytek i wręcz konieczność korzystania z aktualnej kultury prawnej, równocześnie zaś uświadomi, że sięganie do niej musi być zróżnicowane i prowadzi do modyfikacji na terenie kościelnym. Dziś prawo kościelne stoi wobec problemów wyrastających z pluralizmu kultur prawnych. 
domości ${ }^{36}$, a tę kształtuje zawsze Objawienie przyjęte przez ludzi w ich konkretnych sytuacjach życiowych. Wyodrębnienie tych przesłanek tłumaczy się ich charakterem historycznym, który powoduje konieczność wciąż nowego ich odczytywania. Ze względu na ich różnorodność wynikającą z odmiennych, w zależności od uwarunkowań czasu i miejsca, dziejów świata można $w$ odniesieniu do nich sformułować tylko najogólniejsze zasady, wymagające potem aplikacji w konkretnych już sytuacjach.

Powyższe uwagi o teorii prawa kościelnego pozostają bez odniesienia do konkretnych instytucji kanoniczych. Uważamy bowiem, że wskazania takie - chociażby podane na zasadzie przykładu - mogłyby odwrócić uwagę od naszego zasadniczego zamysłu.

$\mathrm{Z}$ pewnością jednak już wtedy, gdy mowa jest dopiero o przesłankach teorii, na dalszym planie rysują się czytelnikowi instytucje, dla których wymienione przesłanki mają szczególne znaczenie. Nie jest to obojętne dla weryfikacji teorii.

\title{
DE THEOLOGICIS ET SOCIOLOGICIS PRAEMISSIS THEORIAE IURIS ECCLESIALIS ELABORANDAE
}

\author{
S u m marium
}

Lectoribus benevolis praesentatur versio polona communicationis propositae in Conventu Internationali Iuris Canonici Romae 14-19 februarii 1977 habiti. Termino theoria utimur hic sensu communissimo tamquam scientiam explicanten aliquam regionem realitatis. Proculdubio ipsa idea theoriae iuris ecclesialis non sine inspiratione scientiarum iuris nata est, cum quibus ius Ecclesiae connexum servare debet et quarum adeptiones, modo in foro ecclesiali utiles sint, mutatis mutandis ad usum transferrendae sunt.

Sermo esse non potest de sola translatione in forum ecclesiasticum generalis theoriae iuris. Cum proposito utimur notione theoria et non theologia iuris ecclesialis. Et hoc duabus ex causis:

1. Notione theoria iuris ecclesialis clare in lucem ponitur obiectum huius scientiae attenta eius functione analogica ad illa generalis theoriae iuris.

2. Notio theologia iuris ecclesialis satis confusa videtur. Ad conclusionem enim de existentia duarum scientiarum iuris Ecclesiae ducere potest, scilicet theologiae et canonisticae. Attamen una sola scientia catholica iuris Ecclesiae existit, qua totum ius ecclesiale complectitur omniaque problemata cum illo connexa, etiam problemata fundamentalia. Introductione notionis theologia iuris canonici indirecte canonistica secerneretur de scientiis theologicis, cum tamen non obstante affinitate pro-

${ }^{36}$ O. Gonzalez Hernandez, Das neue Selbstverständnis der Kirche und seine geschichtichen und theologischen Voraussetzungen [w:] G. Barauna,De Ecclesia. Beiträge zur Konstitution über die Kirche des Zweiten Vatikanischen Konzils. Bd. I, Freiburg 1966, 158. 
fessionali cum iuristis canonistae domum propriam inter scientias theologicas ha. bent, illas nempe, quae modo methodico exponunt et evolvunt Revelationem Divinam ad proclamationem datam.

Absque dubio munus theoriae iuris ecclesialis esset analogicum illi generalis theoriae iuris, quae in scientiis iuris munus fundamentale, criticum et axiologicum exercet. In terreno canonistico tunc tantummodo proderit, si cognitioni et comprehensioni iuris canonici tamquam iuris Ecclesiae-mysterii serviverit. Talis esset finis eius: proponere ius ecclesiale in luce ipsius mysterii, patefacere et exprimere vim et naturam iuris ecclesialis, praesentare eius finem et mechanismi efficientiae, elucidare fundamenta eius obligationis. Realitatem iuridicam Ecclesiae uti signum efficientiae Dei in historia generis humani demonstrando servire debet tamquam. instrumentum ad ordinem iuridicum Ecclesiae efformandum et intelligendum. Cum de praemissis theoriae iuris ecclesialis dicimus, volumus demonstrare eius principia necessaria ut theoria cohaerens sit cum realitate Ecclesiae, eam interpretetur et ideo rursum structuris iuridicis efformandis serviatur. Modellum pro fundamentis theoriae positum reapse ex recta cognitione realitatis deducatur oportet. Simpliciter loquendo: ut theoria iuris ecclesialis qua ordo iuridicus Ecclesiae explanandus est ex genuina cognitione Ecclesiae trahatur. Iuri enim ecclesiali tunc tantum proderi $\hat{\imath}$ cum eius principia praesumptionesque realitatem Ecclesiae in luce eius autoconscientiae actualis exprimerint.

Theoria quae elucidationi phaenomeni iuridici Ecclesiae service vult, non potest initio praetermitti quaestionem de natura Ecclesiae. Ad ius canonicum explanandum interrogandum est quid sit Ecclesia. Exhinc praemissum fundamentale: Ecclesia ut mysterium. Theoria iuris ecclesialis attenta eius fine non potest non respicere, immo uti fundamentum considerationum accipire debet doctrinam de mysterio Ecclesiae. Ecclesia comprehensa uti mysterium canonistis non est aliquid factum, metacanonicum neque veritas antescientifica sed est obiectum laborum canonistarum.

Si ergo volumus elucidare ius ecclesiale tamquam realitatem socialem in mysterio Ecclesiae, necesse est contueri generatim locum realitatis socialis in isto mysterio. Explanationem invenimus in constitutione Lumen gentium, ubi Mysterium Ecclesiae „ob non mediocrem analogiam incarnati Verbi mysterio assimilatur" (n. 8) et munus compaginis socialis enucleatur revocatione ideae organi salutis. Analysi explanationis in const. Lumen gentium datae peracta et conclusionibus ad thema pertinentibus in lucem positis exponuntur praemissa emergentia ex natura Ecclesiae, scilicet: 1. Nova personalitas in Ecclesia, 2. Indoles specifica relationem socialium et proprium iustitiae in Ecclesia, 3. Communio uti bonum in activitate ecclesiali efficiendum.

Sequitur enucleatio activitatis iuridicae Ecclesiae in perspectiva evangelizationis, quae disceptatione quattuor quaestionum peragitur: 1. Legislatio comprehensio ecclesialis vitae fidei, 2. Fons vis obligatoriae iuris ecclesialis, 3 . I us et libertas in Ecclesia, 4. Problema receptionis legis in Ecclesia.

Ultima in parte sermo est de sociologicis praemissis theoriae iuris ecclesialis, quod problema fundamentum in habitudine Ecclesiae ad mundum invenit et ad quaestiones de influxu conditionum temporum super ius ecclesiale et de dependentia eius ab instante cultura iuridica reduci potest. Ergo structurae iuridicae Ecclesiae in servitio mundi exponuntur et de connexu iuris ecclesialis cum cultura iuridica mentio facitur. Conclusio de theologica dimensione praemissorum sociologicorum deducitur 